\title{
Research on Party Building in Higher Vocational Colleges
}

\section{Yu Lin}

Fujian Polytechnic of information Technology (Fuzhou, Fujian, China, 350003)

\begin{abstract}
Under the overall leadership of the party, colleges and universities have established a good education for people's satisfaction and long-term development. The efficient and connotative development is closely related to the party's leadership. In the new era, vocational colleges need to adhere to the ideological guidance of General Secretary Xi Jinping and use political construction. In order to lead, promote the construction of the party, grasp the direction of running a school, strengthen the theory, establish a professional team of cadres to promote the implementation of relevant decisions, and effectively promote the quality of party building work, and provide for Lide Shuren Guaranteed. Keywords: Higher Vocational Colleges; Party Building; Connotation; Party Leadership

At the National Education Conference, General Secretary Xi Jinping emphasized the importance of the party's leadership in education and called on party organizations at all levels and types of schools to have firm convictions, do a good job in the school's party building work, and thoroughly implement the party's educational policy in schools. In all aspects of work, we must pay attention to the party building work of the student branch of higher vocational colleges, promote the promotion and development of its vitality and potential, so that it can play an important role in the quality of higher vocational colleges and the training of national talents.
\end{abstract}

\section{Always put political construction in the first place and strengthen the party's political leadership of the school}

\subsection{Orientation.}

The orientation of higher vocational colleges under socialism is to thoroughly implement the party's educational policy, and at the same time, to cultivate socialist builders and successors with comprehensive development of morality, intelligence, physical fitness, and labor. The socialist modernization drive continuously cultivates new forces to jointly shoulder the great task of national rejuvenation.

\subsection{Forging political loyalty}

The management of all aspects of the party and the management of schools and schools are the key tasks of higher vocational colleges. The various systems in organizational life must be improved to remove political dust, and the political acumen and insight of party members and cadres must be exercised to be strict Political discipline and political rules are required to ensure that party members and cadres have a firm political stand and political responsibility.

\subsection{Highlight political functions}

In the entire process of party building in higher vocational colleges, political standards and requirements must be run through, political indicators are used as rigid indicators for measuring party organizations at all levels, and the administrative functions of party organizations at all levels have been strengthened with institutionalized measures. , We must focus on strengthening the political functions of party organizations at all levels, so that their political leadership and ideological leadership can be significantly improved.

Copyright (C) 2020 Yu Lin

doi: 10.18282/le.v9i7.1516

This is an open-access article distributed under the terms of the Creative Commons Attribution Non-Commercial License

(http://creativecommons.org/licenses/by-nc/4.0/), which permits unrestricted non-commercial use, distribution, and reproduction in any medium, provided the original work is properly cited. 


\section{Effectively strengthen organization construction and build a team of loyal, clean and responsible cadres}

\subsection{Strengthen the leadership of the party committee}

Higher vocational colleges should gradually improve the principle of the party committee and the principal's office meeting room under the principal responsibility system under the leadership of the party committee, clarify the specific content and decision-making procedures of relevant major issues, and conduct key research on the reform and development of the school. Persist in running schools in accordance with the law, administering schools democratically, soliciting opinions on major issues, and promoting the continuous delay of relevant work. Keep in mind the original intention and don't forget the mission, build a working mechanism that directly serves teachers and students, connect with the grassroots, help the grassroots do a good job, clarify development ideas, solve development problems, and pursue single-minded development.

\subsection{Consolidate the construction of grassroots party organizations}

The construction of basic-level party organizations in the party building work of higher vocational colleges is the focus of its work, and it has made every effort to promote the implementation of the "benchmarking for the first" construction plan. First, we should reasonably set up party branches, optimize organizational life, and promote the implementation of the grassroots party building innovation plan; second, optimize the education and training system for party branch secretaries, and launch the cultivation of dual leaders of party branch secretaries for teachers; third, implement the party member pioneer project and carry out party member work Effective supervision and evaluation, follow-up services for graduate party members, and form a perfect party member training system, and establish a school-enterprise party building base. Finally, an innovative party building model of "Internet + party building" will be formed to improve the informatization level of party building.

\section{Continue to strengthen the construction of work style and discipline, and create a political ecology full of righteousness}

\subsection{The style of daxing research}

Higher vocational colleges should take party building as the core, carry out targeted, timely and effective research work, better listen to the opinions of teachers and students, so that party building can serve the overall situation, perform responsibilities, and constantly discover the development of the school The problem should be solved in time.

\subsection{Optimize inspection and supervision}

Higher vocational colleges should form a progressive chain of supervision and supervision, formulate a sound supervision and supervision mechanism, make reasonable use of supervision results, and pay attention to the implementation of supervision work. Guided by results and performance, conduct differentiated assessments, clarify the scope and responsibilities of supervision and supervision, and form a unity of rights, responsibilities, and responsibilities, so that failures to be accounted for, and joint management.

\section{3 layer compaction responsibility}

Party building needs to clarify responsibilities. In higher vocational colleges, a layered responsibility system should be formed, and a complete responsibility system should be established. The principal of the party committee secretary assumes the first responsibility to check the work of the party; the school's main leaders and the leadership team are the main responsibility for work deployment, link coordination, matter supervision, and problem solving; the departments in charge of the leadership team carry out the specific implementation of policies .

\subsection{Strict discipline construction}

Discipline has always been the foundation of party building, and the party building of higher vocational colleges places more emphasis on the implementation of the responsibility system for the construction of party style and clean government in secondary units, and is committed to forming a scientific and effective anti-corruption responsibility system, so that power structure and operating mechanism There is a relationship of mutual restraint and coordination, 
and strict discipline is used to urge party members to be honest in politics.

\section{Concluding remarks}

For a long time, party building has been a complex and complete system of work. The party school building work of higher vocational colleges mainly includes politics, ideology, organization, style, discipline construction, etc., and the foundation and important support of all these It is system construction. Only with a complete and detailed system can the party building of higher vocational colleges be put into practice, and the educational goal of the school's morality and talent can be truly realized. When improving the system, the party committee of higher vocational colleges should not only emphasize the optimization of its depth and details, but also ensure its systemicity, operability and execution ability, so as to strengthen the educating ability of higher vocational colleges and cultivate high Quality successor to socialism with Chinese characteristics.

\section{References}

1. Sun Zhi. Thoughts on strengthening grassroots party building work in higher vocational colleges[J]. Journal of Beijing Vocational College of Finance and Trade, 2020, 36(03): 47-50.

2. Wang Ling. Thoughts and explorations on the construction of grassroots party branches in higher vocational colleges[J]. Knowledge Economy, 2020(18): 81-82.

3. Lu Jia. With political construction as the command, comprehensively strengthen the party building of higher vocational colleges[J]. Journal of Liaoning Transportation College, 2020, 22(02): 55-58. 